\title{
EFFECT OF IRRIGATION INTERVALS, POTASSIUM FERTILIZER RATES AND STORAGE PERIOD ON SORGHUM (Sorghum bicolor L. Mench) SEED VIABILITY AND ITS SEEDLING VIGOR. \\ El-Emam, A. A. M.; I. F. Mersal and M. I. El-Abady \\ Seed Tech. Res. Sec. Field Crops Res. Institute, A.R.C.
}

\begin{abstract}
Storage studies were carried out at seed Technology Unit Lab. Mansoura, Dakahlia during November 2005 till April 2008 on sorghum (Sorghum bicolor L. Mench) seed produced from field experiment which was conducted at the Experimental farm of El-Serw Agriculture Research Station, Dakahlia Governorate in 2005 and 2006 seasons, to study the effect of three irrigation intervals i. e. 14, 21 and 28 days, three potassium fertilizer i. e. 0,24 and $48 \mathrm{Kg} \mathrm{K}_{2} \mathrm{O} / \mathrm{fed}$ and four storage periods i. e. $0,6,12$ and 18 months on germination percentage, seed viability and seedling vigor.

The results revealed that prolong irrigation intervals and storage period reduced germinability (as measured by germination percentage, germination after aging, first count, germination index, germination energy and germination rate) and seedling vigor (seedling length, seedling dry weight and its vigor index), meanwhile, increased mean germination time. Increasing potassium fertilizer rates improved seed viability and seedling vigor traits, on the contrast, decreased mean germination time. High significant effect for the interaction between storage period $\mathrm{x}$ irrigation intervals, storage periods $x$ potassium fertilizer rates and irrigation intervals $x$ potassium fertilizer rates were obtained for all studied traits.

The results suggested that sowing grain sorghum (c.v. Dorado) under limited irrigation conditions and fertilized with $48 \mathrm{Kg} \mathrm{K} \mathrm{K}_{2} \mathrm{O} / \mathrm{fed}$ plays a prominent role in increasing seed quality under impact of storage periods.
\end{abstract}

\section{INTRODUCTION}

The need for increased food production in Egypt requires the continued development of new agricultural lands which mostly suffer from limited irrigation water. Development of such land is rarely possible without irrigation water regime. Suitable fertilization proved helpful in mitigation the adverse effects of water stress and decreases the deterioration of the resultant seed during storage. The choice of plant materials which posses high efficacy of water utilization or high adaptability for saving water would be great advantage in this context. Such adaptation remains effective until stress conditions are sever or prolonged (Saxena, 1985). Grain sorghum crop (Sorghum bicolor L. Monech) is one of the worlds leading cereal crops, providing food, feed, fiber, fuel and chemical/ biofuels feed- stock across a range of environments and production systems. Sorghum plant has an extensive root system and its drought tolerance makes it suitable for limited irrigation conditions. The environment experienced by the mother plant before seed maturity can have large effects on the germination of seed produced 
(Roach and Wulff, 1987). Water deficit was reported to reduce rate and percentage of germination, seedling shoot and root (Sajjan et al., 2004 and Wondimu-Bayu et al., 2005). El Hawary et al. (2008) found that prolonged irrigation intervals decreased seed quality traits, for both germination percentage and rate, plumule length, radical length, seedling dry weight and seed germination after aging.

Status of minerals in plant nutrition was stated to play a critical role in increasing plant resistance to drought stress (Marschner, 1995). One of the mineral nutrients is potassium which has an important effect for increasing plant tolerance to water stress and activates the enzyme system. Increased potassium during the late stages of maturation increased the germinability of sorghum seed (Arnold et al., 1995). El Hawary et al. (2008) recorded that increasing potassium fertilizer rate up to $48 \mathrm{Kg} \mathrm{K} \mathrm{K}_{2} \mathrm{O} / \mathrm{fed}$ increased seed viability and seedling vigor compared with the unfertilized with potassium.

Seeds are living organisms, and the shelf life of the seed is affected by previous plant life cycle and factors as soil nutrition which accumulated in high amounts (during the development of the seed) to be used later during germination (Gokce, 2006) such compositions of seeds appear to play an important role in determining the general storability behavior of seeds (Vijay et al., 2009).

During storage, seed viability was reduced because of mold growth, heating, damage aging and greater insect damage, (FAO, 1983). Prolonging the storage period of sorghum seed showed a reduction in viability (Patil and Jarhad, 1987). Rao et al. (1993) recorded that germination percentage of sorghum seed decreased with increased storage period. Poonam-Singh, et al. (2004) found that shoot length, root length and seedling dry weight of sorghum gradually decreased with an advance in storage period. Organic matter content of grain sorghum did not change in 7-9 storage months, but it decreased from 97.8 to $91.9 \%$ over a 17 - months period (Mashilla Dejene et al., 2006). Seed viability is affected by many factors among them storage method and period (Mashilla Deijene et. al., 2006).

El Hawary et al. (2008) studied the interaction between irrigation intervals and potassium fertilizer rates, they found that at the highest water stress (irrigation every 28 days), application potassium at the rate of $48 \mathrm{Kg}$ $\mathrm{K}_{2} \mathrm{O}$ / fed gave the highest values of seed quality.

The aim of this study was to investigate the effect of different irrigation intervals, potassium fertilizer rates and stored periods on seed viability and seedling vigor of grain sorghum (Sorghum bicolor L. Mench).

\section{MATERIALS AND METHODS}

Storage studies were carried out at seed Technology Unit Lab. Mansoura, Dakahlia during November 2005 till April 2008 on seed produced from field experiment which was conducted at the Experimental farm of ElSerw Agriculture Research Station, Dakahlia Governorate in 2005 and 2006 seasons, to study the effect of three irrigation intervals i. e. 14, 21 and 28 days, three potassium fertilizer i. e. 0,24 and $48 \mathrm{Kg} \mathrm{K} 2 \mathrm{O} / \mathrm{fed}$. and four 
storage periods i. e. $0,6,12$ and 18 months on germination percentage, seed viability and seedling vigor .

Samples of grain sorghum (c.v. Dorado) for field experiment were obtained from Sorghum Crops Research Program at field Crop Research Institute, Agriculture Research Center, Giza, Egypt. Field experiment was laid out in a split plot design with three replications. Irrigation treatments were allocated in the main plots and the sub plots were assigned to potassium fertilizer rates. The area of each sub plot was $10.5 \mathrm{~m}^{2}(6$ ridges $50 \mathrm{~cm}$ apart and $3.5 \mathrm{~m}$ long). All agriculture practices were performed as recommended by Ministry of Agriculture and Land Reclamation.

Three irrigation treatments applied, irrigation every 14 (control), 21 and 28 days throughout the growing season. The irrigation treatments started 35 days after sowing. Three potassium fertilizer rates, i.e. 0,24 and $48 \mathrm{Kg}$ $\mathrm{K}_{2} \mathrm{O}$ /fed were applied in the form of potassium sulphate $\left(48 \% \quad \mathrm{~K}_{2} \mathrm{O}\right)$. Potassium fertilizer was applied at 35 days after sowing date. After harvest, sample of each treatment was sieved, cleaned from husk and dust, then seed moisture content determined according to (ISTA, 1985), it ranged between 12.5 to $13.6 \%$ before stored in cloth bags. Four storage periods, i.e. $0,6,12$ and 18 months were applied under laboratory conditions to determine seed technology characters.

Sorghum seed samples of each storage period were undergo to various laboratory testes for evaluating seed quality traits. These include the following:

Germination percentage and accelerated aging test (Germination after seed aging) were performed according to International Seed Testing Association (ISTA, 1985) and defined as the total number of normal seedlings after 10 days.

First count was performed according to International Seed Testing Association (ISTA, 1985).

Germination rate defined according to Bartlett (1937).

$$
\text { Germination rate }=\frac{a+(a+b)+(a+b+c)+\ldots \ldots \ldots+(a+b+c+m)}{n(a+b+c+\ldots \ldots \ldots \ldots+m)}
$$

Where $(a, b$ and $m)$ number of seedlings emerged at the first count, second count and final count and (n) is the number of counts.

Germination index and Mean germination time were performed according to Alvarado and Bradford (1987).

Germination index $=\frac{\mathrm{N}_{1}+\mathrm{N}_{2}+\mathrm{N}_{3}+\mathrm{N}_{4}}{\mathrm{Ti}}$

$\mathrm{N}_{1}, \mathrm{~N}_{2}, \mathrm{~N}_{3}$ and $\mathrm{N}_{4}=$ First, second, third and four counts, respectively

$\mathrm{Ti}=$ Count time. 


$$
\text { Mean germination time }=\frac{\left(N_{1} \times T_{1}\right)+\left(N_{2} \times T_{2}\right)+\left(N_{3} \times T_{3}\right)+\left(N_{1} \times T_{4}\right)}{N_{1}+N_{2}+N_{3}+N_{4}}
$$

$\mathrm{N}_{1}, \mathrm{~N}_{2}, \mathrm{~N}_{3}$ and $\mathrm{N}_{4}=$ First, second, third and four counts, respectively.

$T_{1}, T_{2}, T_{3}$ and $T_{4}=$ Time of first, second, third and four counts, respectively) Seedling vigor index $=$ S D W X G. P.

S. D. $W=$ Seedling dry weight.

G. P. = Germination percentage.

Germination energy defined according Ruan et al. (2002).

Germination energy $=\frac{N_{1}+N_{2}}{M} \times 100$

$N_{1}$, and $N_{2}=$ First and second counts

$\mathrm{M} \quad=$ Total number of seeds planted

At the final count, ten normal seedlings from each replicate were taken randomly to measure seedling length (plumule + radical length $\mathrm{cm}$ ), after then, the seedlings were dried in hot-air oven at $85^{\circ} \mathrm{C}$ for 12 hours to obtain the seedling dry weight (g) according to Krishnasamy and Seshu (1990).

Collected data for each season were statistically analyzed by the technique of analysis of variance and the least significant differences (L.S.D.) of treatments (Gomez and Gomez, 1984). Bartlett test was done to the homogeneity of error variances. The test was insignificant for all traits except germination percentage and germination after aging, thus the data of both years were combined for all traits except these traits only

\section{RESULTS AND DISCUSSION}

Data in Table 1 show that the effect of irrigation intervals, potassium fertilizer rates and storage periods on studied traits. Significantly effected were noticed for the irrigation intervals on seed viability and seedling vigor. Germination percentage and germination after aging reached its highest means (87, 87 and $78,79 \%$ ) in the first and second seasons, respectively, at 14 days irrigation intervals. Meanwhile these means reduced to $(83,82$ and $70,71 \%$ ) in the first and second seasons, respectively, with increasing irrigation intervals to 28 days. The same trend was obtained for first count, germination rate, germination energy, germination index, seedling length, seedling dry weight and seedling vigor index. On contrast, mean germination time increased from 3.5 to 4.3 days with increasing irrigation intervals from 14 to 28 days. Drought produce smaller seed size contain less starch reserves which potentially reduced germination capacity and less seedling vigor (Nigel and Jan, 2000). These results are in agreement with those reported by Sajjan et al. (2004), Wondimu-Bayu et al. (2005) and El Hawary et al. (2008). They found that prolonging irrigation intervals decreased seed quality traits, as well as germination percentage and rate, plumule length, radical length, seedling dry weight and germination after aging of the produced sorghum seed in both seasons. 
Significant effects were found fore the potassium fertilizer rates on the studied traits in Table 1 . The highest means values of germination percentage $(87 \%)$ and germination after aging $(76 \%)$ were obtained from treating with potassium fertilizer rate up to $48 \mathrm{Kg} \mathrm{K}{ }_{2} \mathrm{O} / \mathrm{fed}$. On the other side, the lowest means $(83,83 \%$ and $71,73 \%$ ) were obtained from potassium fertilizer rates at $0 \mathrm{Kg} \mathrm{K} 2 \mathrm{O} / \mathrm{fed}$ in the first and second seasons, respectively. The same trends were recorded for first count, germination rate, germination energy, germination index, seedling length, seedling dry weight and seedling vigor index. On the other hand, mean germination time decreased from (4.1 to 3.7 days) under potassium fertilizer rates 0 to $48 \mathrm{Kg} \mathrm{K} 2 \mathrm{O} / \mathrm{fed}$. The increase in seed quality characters might be attributed to the increase of dry matter accumulation and potassium stored in seeds. While potassium fertilizer had important role in potassium activation of enzymes in plant tissues. Increasing dry matter in seeds by enzymes enhancing germination rate and seedling growth, hence, the quality of seed increased by potassium fertilization. Similar results were reported by other investigators among them Patil and Jarhad (1987), Arnold et al. (1995) and El Hawary et al. (2008).

Table 1: Effect of irrigation intervals, potassium fertilizer rates and storage Periods on sorghum seed viability and seedling vigor traits.

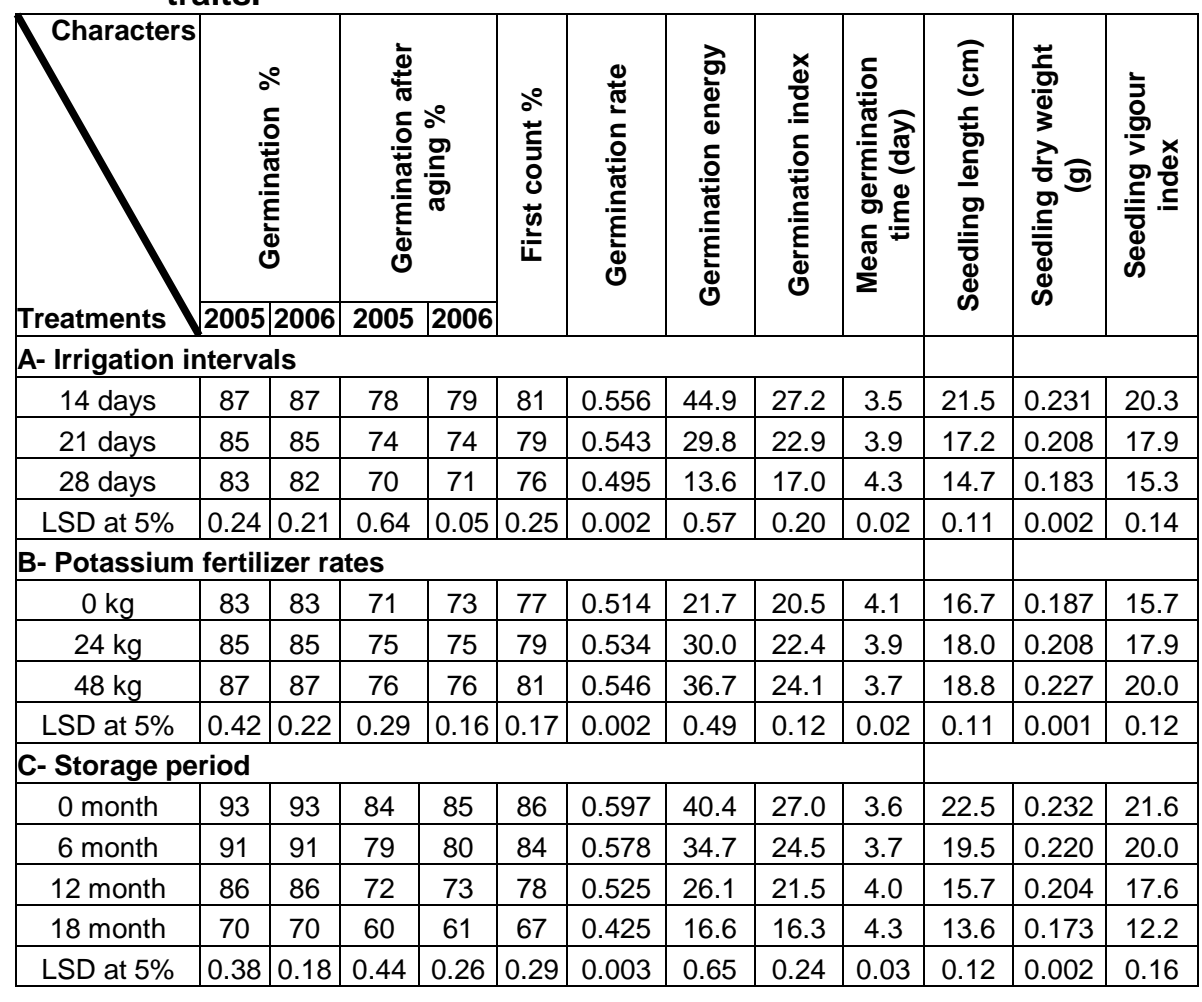


They found that increasing potassium during the late stages of maturation increased the germinability of sorghum seed, also increasing potassium fertilizer rate up to $48 \mathrm{Kg} \mathrm{K} \mathrm{K}_{2} \mathrm{O} / \mathrm{fed}$ increased seed viability and seedling vigor as compared with non- potassium fertilizer. Umar (2006) recorded that increase of concentration of $\mathrm{K}^{+}$in leave which plays a vital role in increasing water stress resistance and stabilizing yield in the sorghum.

Table 1 also shows that the effect of storage periods on studied traits were significant. Germination percentage significantly reduced with increasing storage period from 0 to 18 months. The highest means (93 and $93 \%)$ was obtained at the first storage period. On the other side, the lowest mean (70 and $70 \%)$ was obtained after 18 months from storage in the first and second seasons, respectively.

The same trend was obtained for germination after aging (84, 85 and $60,61 \%)$, first count, germination rate, germination energy and germination index in the first and second seasons, respectively. On contrast, the minimum range of mean germination time (3.6 days) was obtained at the first storage period while the maximum range of mean germination time (4.3 days) was obtained after 18 months from storage. The tallest seedling length $(22.5 \mathrm{~cm})$ were obtained at the first storage period while, the shortest length $(13.6 \mathrm{~cm})$ of seedling length were recorded after 18 months from storage. As a result of that seedling dry weight and seedling vigor index had the same trends. The reduction in seed viability and seedlings vigor traits might be due to increasing storage periods, sorghum seeds might be infested with stored pests (insects and fungi) or might be due to, the increase of some organic compounds consumption during respiration process with increasing storage periods. Similar results were reported by Bekheit et al. (1983), Rao et al. (1993), Poonam-Singh et al. (2004) and Govender and Kritzinger (2008). They found that seed viability and seedling vigour of sorghum gradually decreased with an advance in storage period.

The data presented in Table 2 revealed high significant effect for the interaction between storage periods and irrigation intervals on all studied traits. Germination percentage and germination after aging produced its highest means $(94 \%)$ and $(87 \%$ and $88 \%)$ at 14 days irrigation intervals initially after treatment. Meanwhile, it reduced to $(67 \%$ and $66 \%)$ and $(56 \%$ and $57 \%$ ) after storage with 18 months at 28 days irrigation intervals in the first and second seasons, respectively. The same trend was noticed for the first count, germination rate, germination energy and germination index on contrast, mean germination time reached its earlier time 3.2 days at 14 days irrigation intervals at the first storage period and its lately time 4.9 days at 28 days irrigation intervals after 18 months from storage. seedling length, seedling dry weight and seedling vigor index produced their highest means at 14 days irrigation intervals at the first storage period meanwhile, these traits produced their lowest means after 18 months of storage at the high irrigation intervals 28 days. The reduction in seed viability or seedlings vigor with increasing the storage period might be due to increasing insect infestation or from the increase of some organic compounds consumption during respiration process. These results are similar with those reported by Girish et al. (1976). 
Table 2: Effect of the interaction between storage periods and irrigation intervals on sorghum seed viability and seedling vigor traits.

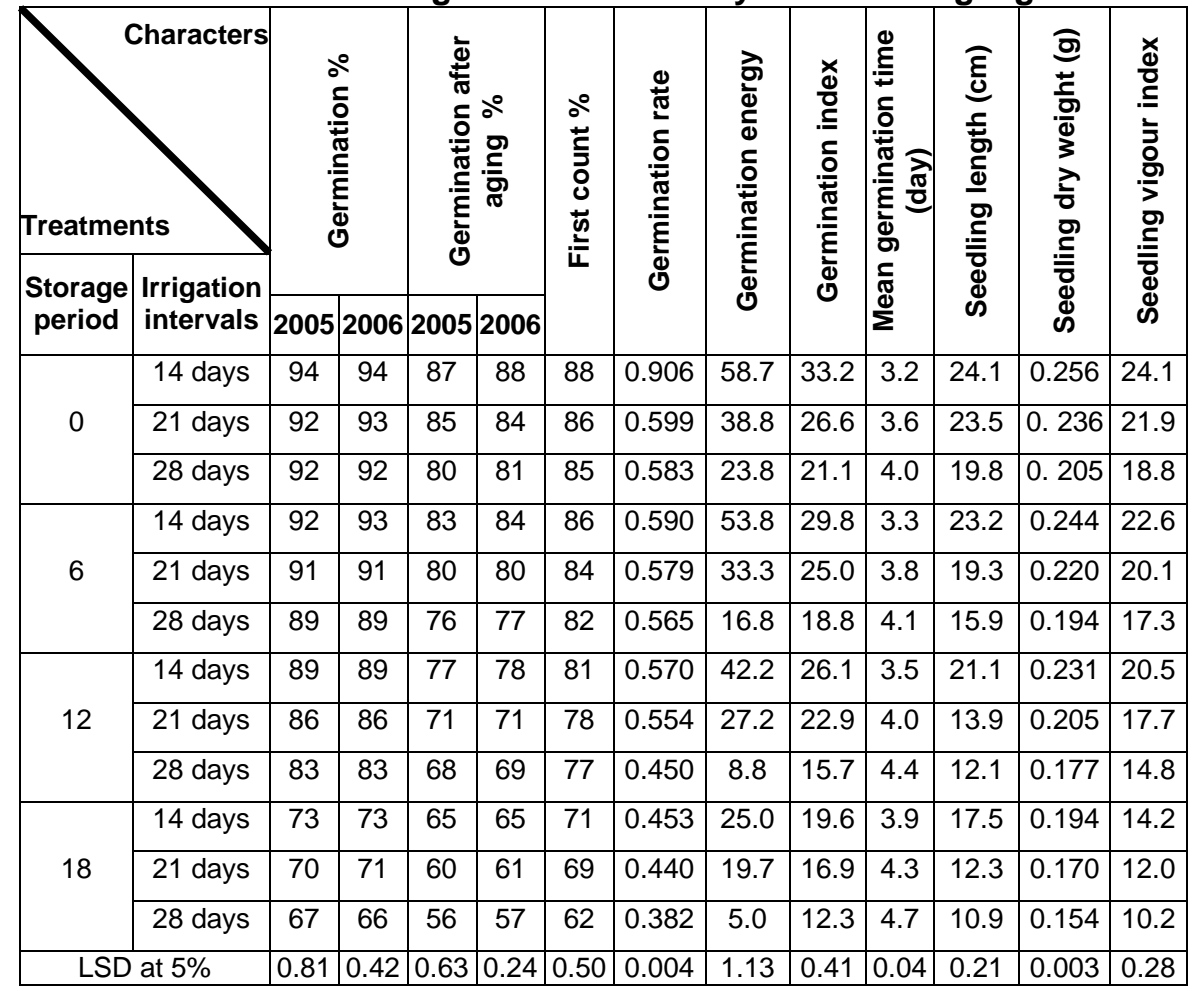

Data in Table 3 showed high significant effects for the interaction between storage period and potassium fertilizer rates. The highest mean values of germination percentage and germination after aging (95 and 95\%) and (87 and $86 \%)$, respectively, were obtained from treated plants with potassium fertilizer at the rate of $48 \mathrm{Kg} \mathrm{K} 2 \mathrm{O} / \mathrm{fed}$ at the first storage period. Meanwhile, the lowest means of these traits (68 and 68\%) and (59 and 60\%) were recorded after storage with 18 months and potassium fertilizer rate with $0 \mathrm{Kg} \mathrm{K}{ }_{2} \mathrm{O} / \mathrm{fed}$. The same trends were noticed for the first count, germination rate, germination energy and germination index, seedling length, seedling dry weight and seedling vigor index. On the other hand, mean germination time was increased from 3.4 days at the first storage period under fertilized with $48 \mathrm{Kg} \mathrm{K} \mathrm{K}_{2} \mathrm{O}$ to 4.5 days at $0 \mathrm{Kg} \mathrm{K} \mathrm{K}_{2} \mathrm{O}$ after 18 months from storage. The increase in quality characters might be attributed to the increase of dry matter accumulation and potassium stored in seeds. While potassium fertilizer had important role in potassium activation of enzymes in plant tissues. Increasing matter in seeds by enzymes enhancing germination rate and seedling growth hence, the quality of seed increased by potassium fertilization (Arnold et al., 1995). 
Table 3: Effect of the interaction between storage periods and potassium fertilizer rates on sorghum seed viability and seedling vigor traits.

\begin{tabular}{|c|c|c|c|c|c|c|c|c|c|c|c|c|c|}
\hline Trea & & & 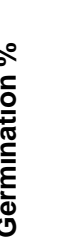 & 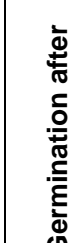 & 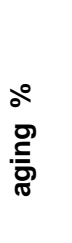 & 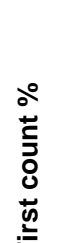 & 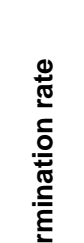 & 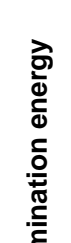 & 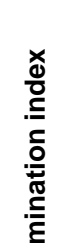 & 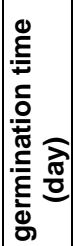 & 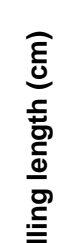 & 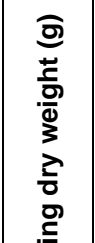 & 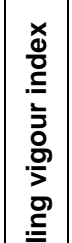 \\
\hline $\begin{array}{l}\text { Storage } \\
\text { periods }\end{array}$ & $\begin{array}{l}\text { potassium } \\
\text { fertilizer }\end{array}$ & & 20 & 2005 & 2006 & & & 屯 & త & 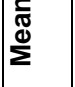 & ๗ & $\begin{array}{l}\text { ¿ } \\
\text { ळ }\end{array}$ & ஸ் \\
\hline & & 90 & 91 & 80 & 83 & 84 & 581 & 31.6 & 24.6 & 3.8 & 21.4 & 0.212 & 19.2 \\
\hline 0 & 2 & 93 & 93 & 85 & 85 & 87 & .595 & 42.3 & 27.3 & 3. & 22.6 & .232 & 21.6 \\
\hline & & 95 & 95 & 87 & 86 & 89 & 0.614 & 47.4 & 28.9 & 3. & 23.3 & 0.253 & 24.0 \\
\hline & & 88 & 89 & 77 & 78 & 82 & 0.564 & 27.0 & 22.5 & 4.0 & 18.5 & 0.199 & 17.6 \\
\hline 6 & $24 \mathrm{Kg}$ & 91 & 91 & 80 & 81 & 84 & 0.579 & 35.3 & 24.7 & 3.7 & 19.6 & 0.221 & 20.2 \\
\hline & $3 \mathrm{Ka}$ & 9 & 93 & 81 & 82 & 86 & 590 & 41.7 & 26.4 & 3.5 & 20.3 & 0.239 & 22 \\
\hline & & 84 & 84 & 65 & & 7 & & 20 & 20.0 & 4. & 14.5 & & \\
\hline 12 & & 86 & 86 & 7 & 74 & 78 & 3 & 24.7 & 21.5 & 4. & 15.9 & 0.205 & \begin{tabular}{|l|}
17.7 \\
\end{tabular} \\
\hline & & 88 & 87 & 74 & 74 & 80 & 6 & 32.7 & 23.1 & 3. & 16.7 & 0.227 & 19.9 \\
\hline & & 68 & 68 & 59 & 60 & 5 & 3 & 7.2 & 14.8 & 4.5 & 12.3 & .156 & 10.7 \\
\hline 18 & $\mathrm{Kg}$ & 70 & 70 & 61 & 61 & 68 & 0.430 & 17.7 & 16.3 & 4.2 & 13.5 & 0.173 & 12.1 \\
\hline & $48 \mathrm{Kg}$ & 72 & 71 & 62 & 62 & 69 & 0.442 & 24.8 & 17.8 & 4.1 & 15.0 & \begin{tabular}{|l|}
0.191 \\
\end{tabular} & 13.4 \\
\hline & & 0.79 & 0.41 & 0.56 & 0.29 & 0.33 & 0.004 & 0.97 & 0.12 & \begin{tabular}{|l|}
0.03 \\
\end{tabular} & 0.19 & 0.003 & 0.25 \\
\hline
\end{tabular}

The data concerned the effect of the interaction between irrigation intervals and potassium fertilizer rates are recorded in Table 4. High significant effects were noticed on all studied traits.

Table 4: Effect of the interaction between irrigation intervals and potassium fertilizer rates on sorghum seed viability and seedling vigor traits.

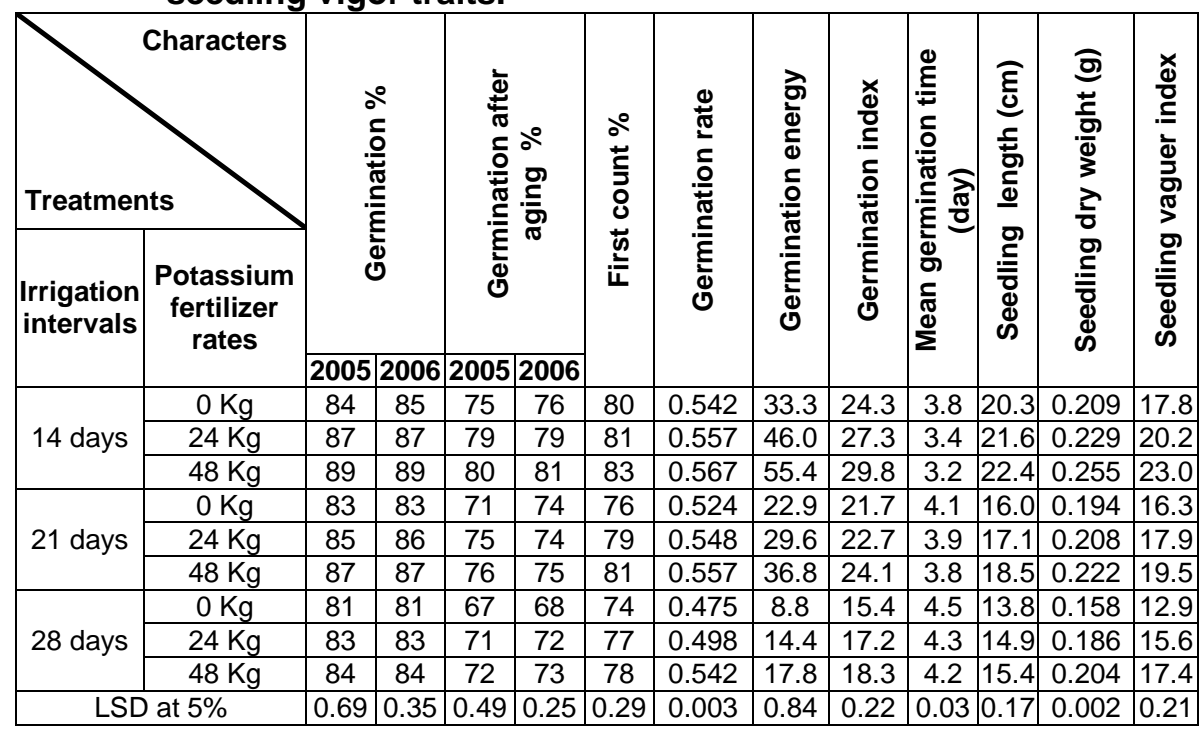


At the lowest irrigation intervals (14 days), germination percentage, germination after aging, seed viability and seedling vigor traits had the highest means values under the three potassium fertilizer rates $(0,24$ and 48 $\mathrm{Kg} \mathrm{K}_{2} \mathrm{O}$ ). ON contrast, the lowest mean values of these traits were recorded at irrigation intervals 28 days at potassium fertilizer rates $0 \mathrm{Kg} \mathrm{K} \mathrm{K}_{2} \mathrm{O}$. Also mean germination time was increased gradually with increasing irrigation intervals from 14 to 28 days especially with potassium fertilizer rate at $0 \mathrm{Kg}$ $\mathrm{K}_{2} \mathrm{O}$. These results suggested that increasing potassium rate alleviated the inhibitor effect of seed viability and seedling vigor of grain sorghum. These results are in agreement with those of El Hawary et al. (2008).

\section{REFERENCES}

Alvarado, A.D. and K. J. Bradford (1987). Priming and storage of tomato (Lycopersicum esculentum) seeds. I. Effect of storage temperature on germination rate and viability. Seed Sci. and Technology, 16: 601-612.

Arnold, R. L. B.; M. Fenner and P. J. Edwards (1995). Influence of potassium nutrition on germinability, abscisic acid content and sensitivity of the embryo to abscisic acid in developing seeds of Sorghum bicolor (L.) Moench. New-Phytologist, 130(2): 207-216.

Bartlett, M. S. (1937). Some samples of statistical method of research in agriculture and applied biology. J. Roy. Soc., 4:2.

Bekheit, R. B.; A. M. Amein and A. M. El-Shabrawy (1983). Effect of some seed borbe fungi on certain sorghum grain characters under natural and controlled condition of storage. Assuit, J. Agric. Sci., 14(4) 299312.

El Hawary, M. A.; A. A. M. El- Emam and I. F. Mersal (2008). Effect of irrigation intervals and potassium fertilizer rates on yield and seed quality of some sorghum cultivars. J. Agric. Sci. Mansoura Univ., 33 (5): 3151-3165.

F. A. O. (1983). Food and Agriculture Organization of the united Nations Rom, 1983, pp61.

Gokce, O. (2006). Identification of zinc binding proteins of wheat seed . M.Sc. Thesis, Graduate School of Engineering and natural Sci.,Sabanci Univ. (C.F. Computer Search).

Gomez, K. A. and A. A. Gomez (1984). Statistical procedures for agricultural research. $2^{\text {nd }} E d$. John Whley \& Sons.

Govender, V.; T .A .S. Aveling and Q. Kritzinger (2008). Effect of traditional storage methods on germination and vigour of mais (Zea mays $L$.) from northern Kwazulu-Natal and southern Mozambique. South African J. of Botany, 74: 190-196.

Girish, G. K.; B. P. Tripathi; R. P. S. Tomer and K. Krishnamuthy (1976). Studied on the assessment of losses. IV. Conventional grain storage practices and losses in rural areas in Utter Pradesh. Rev. App. Entomol., Series A, 64(7): 1241.

I. S. T. A. (1985). International Rules for Seed Testing, Seed Science and Technol. $13: 307-355$. 
Krishnasamy, V. and D.V. Seshu (1990). Phosphine fumigation influence on rice seed germination and vigor. Crop Sci., 22: 28- 85.

Marschner, H. (1995). Mineral nutrition of higher plants $2^{\text {nd }}$ ed Academic Press San dies California- USA. (C.F. Computer Search).

Mashilla Dejene; J. Yueen and R. Sigvald (2006). Effect of storage methods, storage time and different agroecological zones on chemical components of stored sorghum grain in Hararghe, Ethiopia. J. of Storage Products Res. 42: 445-456.

Nigel, P. and E. Jan (2006). Cereal seed quality after drought. NSW DPI (C.F. Computer Search).

Patil, R. B. and A. L. Jarhad (1987). Viability of sorghum inbred seeds stored under different containers. J.-of-Maharashtra-Agric.-Univ., 12(3): 355358.

Poonam-Singh; Nalini-Tewari and S. K. Swarnkar (2004). Effect of containers on the storability of (Sorghum bicolor L.) seed, Progressive-Agriculture. 4(1): 74-75.

Roach, D. A. and R. D. Wulff (1987). Maternal effects in plants. Annual Review of ecology and systematics, 18, 209-235.

Rao, D. V. S. R.; B. M. Reddy; R. Ankaiah; K. G. R. S. Saibabu and S. H. Hussaini (1993). Influence of sieve size on storability of $\mathrm{CSH}-5$ sorghum hybrid. J.-of-Res.-APAU, 21(3): 163-164. (C.F. Computer Search).

Ruan, S.; Q. Xue and K. Tylkowska (2002). Influence of priming on germination of rice (Oryza sativa L.) seed and seedling emergence and performance in flooded soil. Seed Sci. and Technology, 30: 61-67.

Sajjan, A. S.; K. N. Pawar; M. S. Dhamaleppagol and B. D. Biradar (2004). Influence of water stress treatments on seed quality of sorghum genotypes. Crop Res. Hisar, 27 (1) : 46-49.

Saxena, N. P. (1985). The role of potassium in drought tolerance. Potash review. No. 5. International Potash Institute, Bern-16: 1-15.

Umar, S. (2006). Alleviating adverse effects of water stress on yield of sorghum, mustard and groundnut by potassium application. Pakistan $\mathrm{J}$. Bot., 38 (5)1373-1380.

Vijay, D.; M. Dadlani and S. Nagarajan (2009). Role of sorption properties and water status in control of seed longevity patterns. Current Science 96,8,1103-1109.

Wondimu-Bayu; N. F. G. Rethman; P. S. Hammes; P. A. Pieterse; J. Grimeek and M-Van-der Linde (2005). Water stress affected the germination, emergence and growth of different sorghum cultivars. Sinet, Ethiopian J. of Sc., 28(2): 119-128. 
تأثير فترات الري ومعدلات التسميد البوتاسي و مدة التخزين على حيويـة البذور

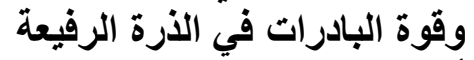

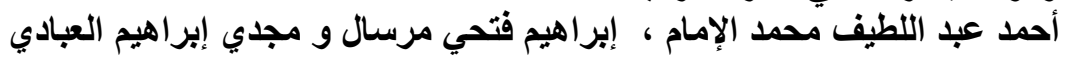

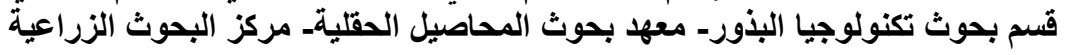

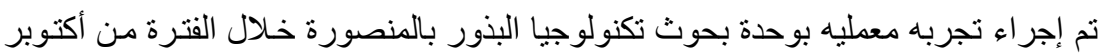

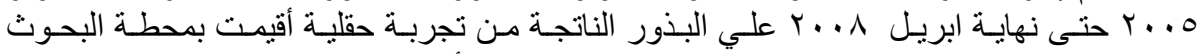

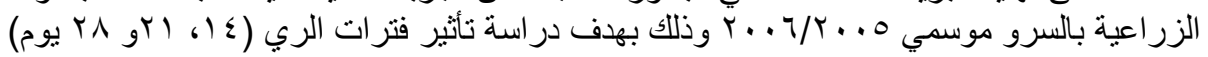

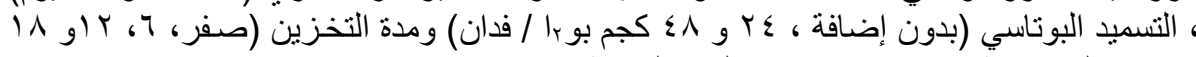

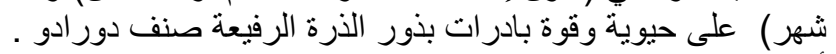
أوضحت النتائج:-

زيادة فترة التخزين وفترات الري أدت إلى نقص كل من الحيوية (تم قياسها بالنسبة المئوية

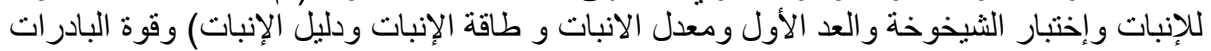

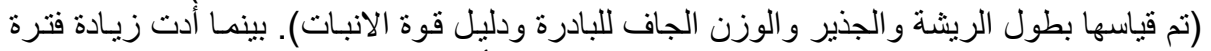

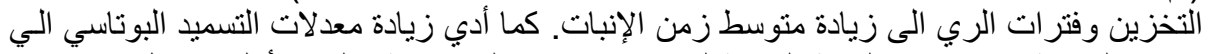

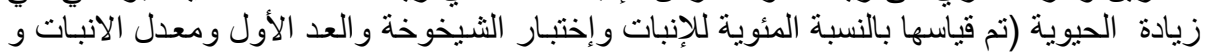

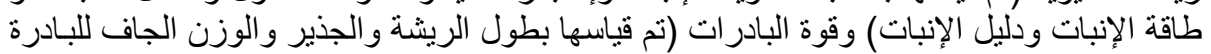

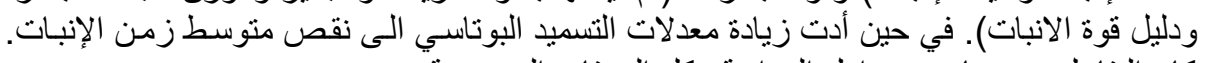

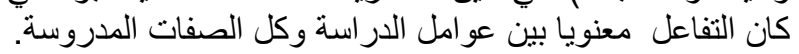

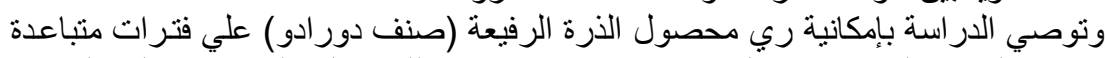

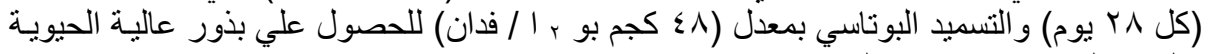
والجودة لمدة r ا شهر من التخزين.

كلية الزراعة - جامعة المنصورة

$$
\text { قام بتحكيم البحث }
$$

مركز البحوث الزراعية

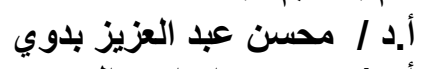

أ.د / محمود إبراهيم العميري بدي العزي 